\title{
Dioxin and furan blood lipid concentrations in populations living near four wood treatment facilities in the United States
}

\author{
C. Wu, L. Tam, J. Clark \& P. Rosenfeld \\ Soil Water Air Protection Enterprise, USA
}

\begin{abstract}
To evaluate historical exposure from wood treatment facilities, blood samples were collected from 65 current and past residents of four communities surrounding wood treatment facilities throughout the United States. The pattern of dioxin/furan congeners detected in blood samples was found to be consistent with exposure to contaminants generated during the wood treatment process. The levels of 2,3,7,8-tetrachloro-p-dibenzodioxin toxic equivalents $(2,3,7,8$-TCDD TEQs) for all 17 carcinogenic dioxin/furan congeners, octa-chlorinated dibenzop-dioxins (OCDD) adjusted to its TEQ value and 1,2,3,4,6,7,8-hepta-chlorinated dibenzo-p-dioxin $(1,2,3,4,6,7,8-H p C D D)$ adjusted to its TEQ value in the U.S. population were compared to the TEQ levels of the combined dataset for all 4 communities and of the datasets for each individual community. TEQ concentrations in these communities were found to be significantly greater than the TEQ data for the general U.S. population. These findings reveal that a very significant potential for contaminant-related health risks exists in communities surrounding wood treatment facilities.
\end{abstract}

Keywords: wood treatment, blood analysis, dioxins, furans, creosote, pentachlorophenol.

\section{Introduction}

In this study, total 2,3,7,8-tetrachloro-p-dibenzodioxin toxic equivalents $(2,3,7,8$ TCDD TEQs) (all 17 carcinogenic dioxin/furan congeners), octa-chlorinated dibenzo-p-dioxin (OCDD) (adjusted to its TEQ value), and 1,2,3,4,6,7,8-heptachlorinated dibenzo-p-dioxin $(1,2,3,4,6,7,8-H p C D D)$ (adjusted to its TEQ value) in blood for residents living in four communities including Alexandria, 
Louisiana; Pineville, Louisiana; Grenada, Mississippi; and Florala, Alabama surrounding wood treatment facilities in the United States were evaluated. The facilities used pentachlorophenol (PCP) and creosote as insecticides to treat wood and released dioxins and other hazardous substances into the surrounding communities. The Alexandria, LA facility has been in operation since 1926, the Pineville, LA facility has been in operation since 1948, the Florala, AL facility has been in operation since the early 1900s, and the Grenada, MS facility has been in operation since 1904 .

Dioxins and furans are by-products and impurities generated and released during human activities such as industrial, municipal, and domestic incineration/combustion processes and during the manufacture of chlorinated phenols and other chlorinated chemicals like PCP [1-4]. Polychlorinated dibenzo-p-dioxin (PCDD) and polychlorinated dibenzofuran (PCDF) are toxic chlorinated compounds that are usually released as mixtures into the environment. The use and incineration of PCP and creosote-treated wood products creates highly chlorinated dioxin and furan congeners, such as the signature congeners OCDD and 1,2,3,4,6,7,8-HpCDD [5-9].

There are 210 different dioxin and furan congeners. Seventy-five are possible dioxin congeners and 135 are possible furan congeners. The dioxin and furan congeners thought to be most toxic to humans are the seven dioxins and ten furans with a particular pattern of chlorines known as the 2,3,7,8-congeners. These 17 congeners are reported to cause cancers, and have endocrine and reproductive effects. The different $\mathrm{PCDD} / \mathrm{F}$ congeners are structurally similar and have a similar mechanism of action. These chemicals are typically evaluated as 2,3,7,8-TCDD TEQs [10].

Human blood sampling is used for evaluating and assessing historical exposure to contaminants $[6,7,11]$. Dioxins and furans have relatively long halflives in human blood, therefore, sampling human blood can also be used to assess historical exposure. Pirkle et al. [12] estimated the serum half-life of 2,3,7,8-TCDD in humans to be 7.1 years (range of 2.9-26.9 years) in a group of 36 Vietnam veterans. In a subsequent study, Michalek [13] estimated the serum half-life of 2,3,7,8-TCDD in humans to be 8.7 years (95\% CI of 8.0-9.5 years) in a group of 343 Vietnam veterans. A half-life range from 3.5 to 15.7 years was estimated for dioxin congeners other than 2,3,7,8-TCDD in a study performed by Flesch-Janys et al. [14].

To evaluate whether exposure contamination in the communities surrounding wood treatment facilities were higher than the general US population, blood samples were compared to the Center for Disease Control (CDC) National Health and Nutrition Examination and Survey (NHANES) dataset for 2003 to 2004. The Centers for Disease Control and Prevention (CDC) conducts a survey, the National Health and Nutrition Examination Survey (NHANES), every two years through the National Center for Health Statistics (NCHS). The NHANES data set contains health and nutritional information on the U.S. population. The 1999-2000 survey collected data on 116 chemicals and was the first to include PCDD/F serum analyses. The 2001-2002 NHANES survey 
collected data on 135 chemicals. The data was yet again updated in 2003-2004 $[15,16]$.

The NHANES dataset was used as descriptive reference statistics for 2,3,7,8TCDD TEQ in blood-lipid in the U.S. population. The results of blood sampling in the communities adjacent to the wood treatment facilities were compared to the NHANES dataset and found to be significantly greater than the 2,3,7,8TCDD TEQ concentrations in the NHANES dataset.

\section{Materials and methods}

\subsection{Blood sampling and analysis}

Blood samples were collected from 65 current and past residents of the communities immediately surrounding wood treatment facilities and analyzed to evaluate levels of dioxins and furans. Samples were then shipped to Severn Trent Laboratories (STL) in Sacramento, CA for analysis.

In accordance with USEPA Method 8290, STL used high-resolution gas chromatography (HRGC)/mass spectrometry (HRMS) to analyze the blood samples. Each serum sample was spiked with ${ }^{13} \mathrm{C}_{12}$-labeled internal standards prior to extraction. A DB-5 capillary column was used to separate the target analytes. Each sample batch included a Method Blank (MB), a Laboratory Control Sample (LCS), and the unknown serum samples. Blood lipid content was determined gravimetrically. Data was reviewed using comprehensive multitiered quality assurance and quality control procedures.

To efficiently evaluate mixtures of PCDD/Fs, Toxic Equivalency Factors (TEFs) were developed [17]. TEFs establish the toxicity of the different congeners in relation to 2,3,7,8-TCDD for use in evaluating human health concerns. The EPA has determined that TEFs are currently the best method for evaluating complex mixtures of PCDD/Fs. The concentration of each PCDD/F is multiplied by its respective TEF to obtain a 2,3,7,8-TCDD toxic equivalents (TEQ) value [18]. These individual TEQs are then summed to provide a total dioxin TEQ value [19]. TEQ values for individual congeners can also be calculated by multiplying the concentration of the congener by the TEF value. The two individual congeners evaluated in this study are OCDD and $1,2,3,4,6,7,8-\mathrm{HpCDD}$ with TEF values of 0.0003 and 0.01 respectively.

\subsection{NHANES data set analysis}

The 2003 to 2004 NHANES data for dioxins and furans was downloaded from the CDC website [15]. The data was downloaded in SAS format, but converted to Microsoft Excel format using SYSTAT 11.0 statistical software package. The detection limit over the square root of two was substituted for concentrations below the detection limit in all calculations. The CDC uses this method to analyze the NHANES dataset [20]. 2,3,7,8-TCDD TEQs were calculated for the data using the WHO 2005 TEF values and total dioxin TEQs were summed for each individual. Congener specific analysis was also conducted by calculating 
TEQs for OCDD and 1,2,3,4,6,7,8-HpCDD. The data was then filtered for males and females 25 to 88 years of age to correspond with the complete dataset of all four communities. The data was also filtered for individuals 44 to 88 years of age for the Grenada dataset, 34 to 72 years of age for the Pineville dataset, 37 to 79 years of age for the Alexandria dataset, and 25 to 76 years of age for the Florala dataset to correspond with the individual community datasets. The use and incineration of PCP and creosote-treated wood products creates highly chlorinated dioxin and furan congeners, such as the signature congeners OCDD and 1,2,3,4,6,7,8-HpCDD [5-9]. Therefore, these congeners were isolated from the NHANES dataset for statistical analysis. TEQs were then used to calculate the sum, mean, maximum, minimum and other summary statistics for all congeners and specific congeners in lipid-adjusted serum concentration data.

\subsection{Statistical analysis}

Statistical analysis of the datasets was used to determine if the cohorts' total 2,3,7,8-TCDD-TEQ, OCDD (adjusted to its TEQ value) and 1,2,3,4,6,7,8HpCDD (adjusted to its TEQ value) blood lipid concentrations are statistically different and greater than the general US population of the same age range. The Statistics Online Computational Resource (SOCR) software [21] developed by the University of California, Los Angeles was used for the analysis of the data. The combined four communities, individual community and NHANES datasets are not normally distributed. Therefore, the Wilcoxon rank-sum test, a nonparametric test for assessing whether two samples of observations come from the same distribution, was used to evaluate the datasets.

The Wilcoxon rank-sum tests the null hypothesis that the two sample sets are drawn from a single population, and therefore their probability distributions are equal. The samples must be independent, and the observations must be continuous measurements. The Wilcoxon rank-sum test generates a z-score and $p$-value for the datasets. A large positive or negative z-score indicates that group $\mathrm{A}$ (or B) values exceed the group B (or A) values respectively. The $p$-value is the probability that two groups of datasets come from the same population [22].

Statistical analysis was performed for total 2,3,7,8-TCDD TEQ (all 17 carcinogenic dioxin/furan congeners), OCDD (adjusted to its TEQ value), and $1,2,3,4,6,7,8-\mathrm{HpCDD}$ (adjusted to its TEQ value) blood lipid concentrations for the combined four communities and the individual communities against the NHANES dataset. The age-range of the NHANES dataset was adjusted to match each comparison group.

\section{Results and discussion}

The results of the statistical analysis of the total 2,3,7,8-TCDD TEQ (all 17 carcinogenic dioxin/furan congeners), OCDD (adjusted to its TEQ value), and 1,2,3,4,6,7,8-HpCDD (adjusted to its TEQ value) blood lipid concentrations demonstrate that the populations surrounding the wood treatment facilities combined and individually have statistically higher TEQs in blood lipid than the 
general population of the U.S. of the same age range $(p<0.05)$. Table 1 presents the data statistical summary for the communities and NHANES TEQ blood lipid data. Table 2 presents the Wilcoxon rank-sum test data outputs comparing the NHANES dataset to the combined four communities and the four individual community TEQ blood lipid datasets.

Table 1: $\quad$ Data statistical summary.

\begin{tabular}{|c|c|c|c|c|c|c|}
\hline \begin{tabular}{|c} 
All 4 Sites Compared To \\
NHANES 2003-4 Data (24-88) \\
\end{tabular} & $\begin{array}{l}\text { Group Total } \\
\text { TCDD TEQs } \\
\end{array}$ & $\begin{array}{l}\text { NHANES Total } \\
\text { TCDD TEQs }\end{array}$ & $\begin{array}{c}\text { Group OCDD } \\
\text { TEQs }\end{array}$ & $\begin{array}{c}\text { NHANES } \\
\text { OCDD TEQ } \\
\end{array}$ & $\begin{array}{c}\text { Group } 1,2,3,4,6,7,8- \\
\text { HpCDD TEQs } \\
\end{array}$ & $\begin{array}{c}\text { NHANES } \\
1,2,3,4,6,7,8-H p C D D \\
\text { TEQs } \\
\end{array}$ \\
\hline Count & 65 & 1159 & 65 & 1140 & 65 & 1155 \\
\hline Maximum & 381.95 & 103.70 & 3.68 & 0.98 & 9.09 & 4.56 \\
\hline Mean & 102.67 & 16.45 & 0.44 & 0.11 & 1.66 & 0.42 \\
\hline 50th Percentile & 80.66 & 13.38 & 0.27 & 0.08 & 0.97 & 0.32 \\
\hline 75th Percentile & 131.96 & 21.48 & 0.47 & 0.13 & 2.20 & 0.55 \\
\hline 90th Percentile & 214.14 & 30.47 & 0.82 & 0.22 & 3.42 & 0.83 \\
\hline 95th Percentile & 237.39 & 38.26 & 0.95 & 0.29 & 4.50 & 1.06 \\
\hline Standard Devation & 80.82 & 11.89 & 0.52 & 0.09 & 1.68 & 0.38 \\
\hline $\begin{array}{c}\text { Grenada, MS Compared To } \\
\text { NHANES 2003-4 Data (44-88) }\end{array}$ & \begin{tabular}{|} 
Grenada, MS Total \\
TCDD TEQs
\end{tabular} & $\begin{array}{c}\text { NHANES Total } \\
\text { TCDD TEQs }\end{array}$ & $\begin{array}{l}\text { Grenada, MS } \\
\text { OCDD TEQs }\end{array}$ & $\begin{array}{l}\text { NHANES } \\
\text { OCDD TEQs }\end{array}$ & $\begin{array}{c}\text { Grenada, } M S \\
1,2,3,4,6,7,8-H p C D D \\
T E Q s\end{array}$ & $\begin{array}{c}\text { NHANES } \\
1,2,3,4,6,7,8-H p C D D \\
\text { TEQs }\end{array}$ \\
\hline Count & 22 & 737 & 22 & 724 & 22 & 734 \\
\hline Maximum & 332.51 & 103.70 & 1.69 & 0.98 & 4.67 & 4.56 \\
\hline Mean & 53.41 & 20.75 & 0.39 & 0.13 & 1.26 & 0.51 \\
\hline 50th Percentile & 31.42 & 17.92 & 0.28 & 0.10 & 0.85 & 0.41 \\
\hline 75th Percentile & 50.88 & 25.44 & 0.39 & 0.17 & 1.19 & 0.66 \\
\hline 90th Percentile & 84.99 & 34.70 & 0.69 & 0.26 & 2.19 & 0.95 \\
\hline 95th Percentile & 123.86 & 44.62 & 0.88 & 0.32 & 3.74 & 1.27 \\
\hline Standard Devation & 67.66 & 12.69 & 0.35 & 0.11 & 1.07 & 0.43 \\
\hline $\begin{array}{c}\text { Pineville, LA Compared To } \\
\text { NHANES 2003-4 Data (34-72) }\end{array}$ & \begin{tabular}{|} 
Pineville, LA Total \\
TCDD TEQs
\end{tabular} & $\begin{array}{c}\text { NHANES Total } \\
\text { TCDD TEQs }\end{array}$ & $\begin{array}{l}\text { Pineville, } L A \\
\text { OCDD TEQs }\end{array}$ & $\begin{array}{c}\text { NHANES } \\
\text { OCDD TEQ }\end{array}$ & $\begin{array}{c}\text { Pineville, } L A \\
1,2,3,4,6,7,8-H p C D D \\
T E Q s\end{array}$ & $\begin{array}{c}N H A N E S \\
1,2,3,4,6,7,8-H p C D D \\
T E Q s\end{array}$ \\
\hline Count & 11 & 751 & 11 & 740 & 11 & 749 \\
\hline Maximum & 381.95 & 76.54 & 3.68 & 0.98 & 9.09 & 4.56 \\
\hline Mean & 129.29 & 15.32 & 0.62 & 0.10 & 1.69 & 0.42 \\
\hline 50th Percentile & 105.49 & 13.70 & 0.26 & 0.08 & 0.82 & 0.33 \\
\hline 75th Percentile & 155.30 & 19.43 & 0.35 & 0.12 & 1.30 & 0.54 \\
\hline 90th Percentile & 224.05 & 25.53 & 0.96 & 0.20 & 2.94 & 0.80 \\
\hline 95th Percentile & 303.00 & 30.73 & 2.32 & 0.26 & 6.02 & 1.04 \\
\hline Standard Devation & 102.03 & 9.17 & 1.04 & 0.09 & 2.57 & 0.37 \\
\hline $\begin{array}{l}\text { Alexandria, LA Compared To } \\
\text { NHANES 2003-4 Data (37-79) }\end{array}$ & \begin{tabular}{|c} 
Alexandria, LA \\
Total TCDD TEQs
\end{tabular} & $\begin{array}{c}\text { NHANES Total } \\
\text { TCDD TEQs }\end{array}$ & $\begin{array}{l}\text { Alexandria, } L A \\
\text { OCDD TEQs }\end{array}$ & $\begin{array}{c}\text { NHANES } \\
\text { OCDD TEQs }\end{array}$ & $\begin{array}{c}\text { Alexandria, } L A \\
1,2,3,4,6,7,8-H p C D D \\
T E Q s\end{array}$ & $\begin{array}{c}\text { NHANES } \\
1,2,3,4,6,7,8-H p C D D \\
\text { TEQs } \\
\end{array}$ \\
\hline Count & 11 & 773 & 11 & 761 & 11 & 770 \\
\hline Maximum & 127.80 & 103.70 & 0.59 & 0.98 & 3.54 & 4.56 \\
\hline Mean & 61.23 & 17.21 & 0.26 & 0.11 & 1.05 & 0.45 \\
\hline 50th Percentile & 58.35 & 15.31 & 0.21 & 0.08 & 0.70 & 0.36 \\
\hline 75th Percentile & 70.87 & 22.07 & 0.29 & 0.14 & 0.95 & 0.60 \\
\hline 90th Percentile & 82.37 & 29.16 & 0.47 & 0.22 & 2.40 & 0.89 \\
\hline 95th Percentile & 105.08 & 34.92 & 0.53 & 0.28 & 2.97 & 1.11 \\
\hline Standard Devation & 27.52 & 10.59 & 0.15 & 0.09 & 1.01 & 0.38 \\
\hline $\begin{array}{c}\text { Florala, AL Compared To } \\
\text { NHANES 2003-4 Data (25-76) }\end{array}$ & $\begin{array}{c}\text { Florala, AL Total } \\
\text { TCDD TEQs }\end{array}$ & $\begin{array}{c}\text { NHANES Total } \\
\text { TCDD TEQs }\end{array}$ & $\begin{array}{l}\text { Florala, } A L \\
\text { OCDD TEQs }\end{array}$ & $\begin{array}{c}\text { NHANES } \\
\text { OCDD TEQ }\end{array}$ & $\begin{array}{c}\text { Florala, } A L \\
1,2,3,4,6,7,8-H p C D D \\
T E Q s\end{array}$ & $\begin{array}{c}\text { NHANES } \\
1,2,3,4,6,7,8-H p C D D \\
\text { TEQs }\end{array}$ \\
\hline Count & 21 & 1003 & 21 & 987 & 21 & 1000 \\
\hline Maximum & 267.23 & 76.54 & 1.72 & 0.98 & 7.60 & 4.56 \\
\hline Mean & 162.04 & 14.32 & 0.50 & 0.09 & 2.37 & 0.39 \\
\hline 50th Percentile & 159.69 & 12.23 & 0.42 & 0.07 & 1.87 & 0.30 \\
\hline 75th Percentile & 202.59 & 18.62 & 0.71 & 0.11 & 2.70 & 0.50 \\
\hline 90th Percentile & 234.35 & 25.43 & 0.83 & 0.19 & 3.50 & 0.76 \\
\hline 95th Percentile & 238.15 & 30.75 & 0.91 & 0.24 & 6.62 & 0.96 \\
\hline Standard Devation & 52.95 & 9.23 & 0.38 & 0.08 & 1.77 & 0.35 \\
\hline
\end{tabular}


Table 2: Wilcoxon rank-sum test summary.

\begin{tabular}{|c|c|c|c|c|c|c|}
\hline $\begin{array}{c}\text { All } 4 \text { Sites Compared To } \\
\text { NHANES 2003-4 Data (24-88) }\end{array}$ & $\begin{array}{l}\text { Group Total } \\
\text { TCDD TEQs }\end{array}$ & $\begin{array}{c}\text { NHANES Total } \\
\text { TCDD TEQs }\end{array}$ & $\begin{array}{c}\text { Group OCDD } \\
\text { TEQs } \\
\end{array}$ & $\begin{array}{l}\text { NHANES } \\
\text { OCDD TEQs }\end{array}$ & $\begin{array}{c}\text { Group 1,2,3,4,6,7,8- } \\
\text { HpCDD TEQs }\end{array}$ & $\begin{array}{c}\text { NHANES } \\
1,2,3,4,6,7,8- \\
\text { HPCDD TEQs }\end{array}$ \\
\hline Sample Size & 65 & 1159 & 65 & 1140 & 65 & 1155 \\
\hline Mean & 102.67 & 16.45 & 0.44 & 0.11 & 1.66 & 0.42 \\
\hline Rank Sum & 73614 & 676087 & 69254 & 657361 & 68345 & 676465 \\
\hline Test Statistics & 3867 & 71469 & 6991 & 67109 & 8875 & 66200 \\
\hline Z-score & & -12.19 & & -11.02 & & -10.37 \\
\hline $\mathrm{P}(\mathrm{T}<=\mathrm{t})$ one-tail & & 0.000 & & 0.000 & & 0.000 \\
\hline $\mathbf{P}(\mathrm{T}<=\mathrm{t})$ two-tail & & 0.000 & & 0.000 & & 0.000 \\
\hline $\begin{array}{c}\text { Grenada, MS Compared To } \\
\text { NHANES 2003-4 Data (44-88) }\end{array}$ & $\begin{array}{c}\text { Grenada, } M S \\
\text { Total TCDD } \\
\text { TEQs }\end{array}$ & $\begin{array}{c}\text { NHANES Total } \\
\text { TCDD TEQs }\end{array}$ & $\begin{array}{l}\text { Grenada, MS } \\
\text { OCDD TEQs }\end{array}$ & $\begin{array}{c}\text { NHANES } \\
\text { OCDD TEQs }\end{array}$ & $\begin{array}{r}\text { Grenada, MS } \\
1,2,3,4,6,7,8- \\
\text { HpCDD TEQs }\end{array}$ & $\begin{array}{c}\text { NHANES } \\
1,2,3,4,6,7,8- \\
\text { HPCDD TEQs }\end{array}$ \\
\hline Sample Size & 22 & 737 & 22 & 724 & 22 & 734 \\
\hline Mean & 53.41 & 20.75 & 0.39 & 0.13 & 1.26 & 0.51 \\
\hline Rank Sum & 13260 & 275161 & 14248 & 264384 & 13807 & 272340 \\
\hline Test Statistics & 3208 & 13007 & 1934 & 13995 & 2595 & 13554 \\
\hline Z-score & & -4.84 & & -6.06 & & -5.43 \\
\hline $\mathrm{P}(\mathrm{T}<=\mathrm{t})$ one-tail & & 0.000 & & 0.000 & & 0.000 \\
\hline$P(T<=t)$ two-tail & & 0.000 & & 0.000 & & 0.000 \\
\hline \begin{tabular}{|c|} 
Pineville, LA Compared To \\
NHANES 2003-4 Data (34-72)
\end{tabular} & $\begin{array}{c}\text { Pineville, } L A \\
\text { Total TCDD } \\
\text { TEQs } \\
\end{array}$ & $\begin{array}{c}\text { NHANES Total } \\
\text { TCDD TEQs }\end{array}$ & $\begin{array}{l}\text { Pineville, LA } \\
\text { OCDD TEQs }\end{array}$ & $\begin{array}{l}\text { NHANES } \\
\text { OCDD TEQs }\end{array}$ & $\begin{array}{r}\text { Pineville, } L A \\
1,2,3,4,6,7,8- \\
\text { HpCDD TEQs }\end{array}$ & $\begin{array}{c}\text { NHANES } \\
1,2,3,4,6,7,8- \\
\text { HPCDD TEQs }\end{array}$ \\
\hline Sample Size & 11 & 751 & 11 & 740 & 11 & 749 \\
\hline Mean & 129.29 & 15.32 & 0.62 & 0.10 & 1.69 & 0.42 \\
\hline Rank Sum & 8275 & 282428 & 7621 & 274755 & 6739 & 282441 \\
\hline Test Statistics & 52 & 8209 & 585 & 7555 & 1566 & 6673 \\
\hline Z-score & & -5.63 & & -4.88 & & -3.53 \\
\hline $\mathrm{P}(\mathrm{T}<=\mathrm{t})$ one-tail & & 0.000 & & 0.000 & & 0.000 \\
\hline$P(T<=t)$ two-tail & & 0.000 & & 0.000 & & 0.000 \\
\hline \begin{tabular}{|l} 
Alexandria, LA Compared To \\
NHANES 2003-4 Data (37-79) \\
\end{tabular} & $\begin{array}{c}\text { Alexandria, } L A \\
\text { Total TCDD } \\
\text { TEQs } \\
\end{array}$ & $\begin{array}{c}\text { NHANES Total } \\
\text { TCDD TEQs }\end{array}$ & $\begin{array}{l}\text { Alexandria, } L A \\
\text { OCDD TEQs }\end{array}$ & $\begin{array}{l}\text { NHANES } \\
\text { OCDD TEQs }\end{array}$ & $\begin{array}{c}\text { Alexandria, } L A \\
1,2,3,4,6,7,8- \\
\text { HpCDD TEQs }\end{array}$ & $\begin{array}{c}\text { NHANES } \\
1,2,3,4,6,7,8- \\
\text { HPCDD TEQs }\end{array}$ \\
\hline Sample Size & 11 & 773 & 11 & 761 & 11 & 770 \\
\hline Mean & 61.23 & 17.21 & 0.26 & 0.11 & 1.05 & 0.45 \\
\hline Rank Sum & 8380 & 299340 & 7386 & 290993 & 6540 & 298832 \\
\hline Test Statistics & 189 & 8314 & 1052 & 7320 & 1997 & 6474 \\
\hline Z-score & & -5.45 & & -4.27 & & -3.01 \\
\hline $\mathrm{P}(\mathrm{T}<=\mathrm{t})$ one-tail & & 0.000 & & 0.000 & & 0.001 \\
\hline$P(T<=t)$ two-tail & & 0.000 & & 0.000 & & 0.003 \\
\hline \begin{tabular}{|c|} 
Florala, AL Compared To \\
NHANES 2003-4 Data (25-76) \\
\end{tabular} & $\begin{array}{c}\text { Florala, } A L \\
\text { Total TCDD } \\
\text { TEQs } \\
\end{array}$ & $\begin{array}{c}\text { NHANES Total } \\
\text { TCDD TEQs }\end{array}$ & $\begin{array}{l}\text { Florala, } A L \\
\text { OCDD TEQs }\end{array}$ & $\begin{array}{l}\text { NHANES } \\
\text { OCDD TEQs }\end{array}$ & $\begin{array}{c}\text { Florala, } A L \\
1,2,3,4,6,7,8- \\
\text { HpCDD TEQs }\end{array}$ & $\begin{array}{c}\text { NHANES } \\
1,2,3,4,6,7,8- \\
\text { HPCDD TEQs } \\
\end{array}$ \\
\hline Sample Size & 21 & 1003 & 21 & 987 & 21 & 1000 \\
\hline Mean & 162.04 & 14.32 & 0.50 & 0.09 & 2.38 & 0.39 \\
\hline Rank Sum & 21294.00 & 503506.00 & 19161.50 & 489374.50 & 20.79 & 500937.00 \\
\hline Test Statistics & 0 & 21063 & 1797 & 18931 & 437 & 20563 \\
\hline Z-score & & -7.85 & & -6.49 & & -7.53 \\
\hline $\mathrm{P}(\mathrm{T}<=\mathrm{t})$ one-tail & & 0.000 & & 0.000 & & 0.000 \\
\hline$P(T<=t)$ two-tail & & 0.000 & & 0.000 & & 0.000 \\
\hline
\end{tabular}

Studies correlate exposure to chemicals such as dioxins, furans, and PAHs, with increased risk of developing a variety of diseases. Exposure to dioxins and furans can lead to endocrine disruption, reproductive and developmental defects, immunotoxicity, hepatotoxicity, neurotoxicity, and a variety of cancers $[2,3,23$, 24]. Exposure to PAHs can increase the risk of developing breast, lung, and skin cancer, leukemia, respiratory toxicity, and reproductive toxicity $[25,26]$. Exposure to a mixture of dioxins, furans, and PAHs can significantly increase 
the risk of developing adverse health effects since these chemicals may have additive and synergistic properties [27].

Similar to other studies that have investigated exposure from residing near wood treatment facilities, the levels of dioxins, furans, and PAHs found in human blood in this study further demonstrate that the residential areas have been and are being exposed to potentially unsafe levels of these contaminants due to past management practices of these wood treatment facilities. The pattern of dioxins and furans found in the blood samples is consistent with dust generated during the incineration of PCP and creosote-treated wood. The residents near the wood treatment facilities also have statistically higher concentrations of 2,3,7,8-TCDD TEQs in blood for all carcinogenic dioxin/furan congeners and for the specific congeners associated with PCP than the general population of the U.S. of the same age range. Furthermore, considering dioxin's long half-life in blood, these concentrations are even more significant. Comparing the exposure of residents around these similar sites gives insight into the pattern of exposure that communities adjacent to other wood treatment facilities might experience.

\section{References}

[1] Dougherty, R.C. Human exposure to pentachlorophenol. Pentachlorophenol chemistry, pharmacology, and environmental toxicology, Environmental Science Research 12, ed. K. R. Rao, Plenum Press: New York, p. 355, 1978.

[2] Agency for Toxic Substances and Disease Registry (ATSDR). Toxicological Profile for Chlorodibenzofurans. ATSDR, Atlanta, GA. 1994.

[3] Agency for Toxic Substances and Disease Registry (ATSDR). Toxicological Profile for Chlorinated Dibenz-p-Dioxins (CDDs). ATSDR, Atlanta, GA. 1998.

[4] Webster, T.F. \& Commoner, B. Overview: The Dioxin Debate. Dioxin and Health, Second Edition, eds. A. Schecter and T.A. Gasiewicz, John Wiley \& Sons, Inc.: Hoboken, NJ, pp. 1-53, 2003.

[5] Paepke, O., Ball, M. \& Lis, A. Various PCDD/PCDF patterns in human blood resulting from different occupational exposures. Chemosphere, 25(7-10), pp. 1101-1108, 1992.

[6] Dahlgren, J., Warshaw, R., Horsak, R.D., Parker, F.M. \& Takhar, H. Exposure assessment of residents living near a wood treatment plant. Environmental Research, 92, pp. 99-109, 2003.

[7] Dahlgren, J., Takhar, H., Schecter, A., Schmidt, R., Horsak, R., Paepke, O., Warshaw, R., Lee, A. \& Anderson-Mahoney, P. Residential and biological exposure assessment of chemicals from a wood treatment plant. Chemosphere, 67, pp. S279-S285, 2007.

[8] Agency for Toxic Substances and Disease Registry (ATSDR). Toxicological Profile for Pentachlorophenol. ATSDR, Atlanta, GA. 2001. 
[9] Harnly M., Petreas M., Flattery J. \& Goldman L.. Polychlorinated dibenzo-p-dioxin and polychlorinated dibenzofuran contamination in soil and home-produced chicken eggs near pentachlorophenol sources. Environmental Science and Technology, 34, pp. 1143-1149, 2000.

[10] United States Environmental Protection Agency (USEPA). Interim Procedures for Estimating Risks Associated with Exposures to Mixtures of Chlorinated Dibenzo-p-dioxins and dibenzofurans (CDDs and CDFs) and 1989 update. U.S. Environmental Protection Agency, Risk Assessment Forum, Washington, DC, EPA/625/3-89/016. 1989.

[11] Hensley, A.R., Scott, A., Rosenfeld, P.R. \& Clark, J.J., Attic Dust and Human Blood Samples Collected Near a Former Wood Treatment Facility. Environmental Research, 105(2), pp. 194-199, 2007.

[12] Pirkle, J., Wolfe, W., Patterson, D., Needham, L., Michalek, J., Miner, J., Peterson, M. \& Phillips, D., Estimates of the half-life of 2,3,7,8tetrachlorodibenzop- dioxin in Vietnam veterans of Operation Ranch Hand. J. Toxicol. Environ. Health, 27(2), pp. 165-171, 1989.

[13] Michalek, J.E., Pharmacokinetics of TCDD in veterans of Operation Ranch Hand: 10-year follow-up. J. Toxicol. Environ. Health, 47, pp. 209220, 1996.

[14] Flesch-Janys, D., Becher, H., Jung, D., Konietzko, J., Manz, A. \& Papke, O., Elimination of polychlorinated dibenzo-p-dioxins and dibenzofurans in occupationally exposed persons. J. Toxicol. Environ. Health, 47, pp. 363-378, 1996.

[15] National Center for Health Statistics (NCHS). National Health and Nutrition Examination Survey Data. Hyattsville, MD: U.S. Department of Health and Human Services, Centers for Disease Control and Prevention. 2003.

[16] National Center for Health Statistics (NCHS). National Health and Nutrition Examination Survey Data. Hyattsville, MD: U.S. Department of Health and Human Services, Centers for Disease Control and Prevention. 2005.

[17] United States Environmental Protection Agency (USEPA). Health effects assessment for creosote. United States Environmental Protection Agency Vol: EPA/600/8-88/025 p. 27. 1987.

[18] United States Environmental Protection Agency (USEPA). Exposure and Human Health Reassessment of 2,3,7,8-Tetrachlorodibenzo-p-Dioxin (TCDD) and Related Compounds. December 2003.

[19] Chen J., Wang S., Yu H., Liao P. \& Lee C., Body burden of dioxins and dioxin-like polychlorinated biphenyls in pregnant women residing in a contaminated area. Chemosphere, 65, pp. 1667-1677, 2006.

[20] Centers for Disease Control and Prevention (CDC). Third National Report on Human Exposure to Environmental Chemicals. Department of Health and Human Services. National Health and Nutrition Examination Survey (NHANES). 2005.

[21] Statistical Online Computational Resource (SOCR). UCLA Department of Statistics. Los Angeles, California. 2007. 
[22] Statistica. StatSoft, Tulsa, Oklahoma. 2007.

[23] Mandal, P.K., Dioxin: a review of its environmental effects and its aryl hydrocarbon receptor biology. J. Comp. Physiol. Biol., 175, pp. 221-230, 2005.

[24] Schecter, A. \& Gasiewicz, T.A., (eds). Dioxin and Health, Second Edition, John Wiley \& Sons, Inc.: Hoboken, NJ.

[25] Agency for Toxic Substances and Disease Registry (ATSDR). Toxicological profile for polycyclic aromatic hydrocarbons (PAHs). ATSDR, Atlanta, GA. 1995.

[26] Bostrom, C.E., Gerde, P., Hanberg, A., Jernstrom, B., Johansson, C., Kyrklund, T., Rannug, A., Tornqvist, M., Victorin, K. \& Westerholm, R., Cancer risk assessment, indicators, and guidelines for polycyclic aromatic hydrocarbons in the ambient air. Environ. Health Perspect., 110(suppl 3), pp. 451-489, 2002.

[27] Carpenter D.O., Arcaro K. \& Spink D.C., Understanding the Human Health Effects of Chemical Mixtures. Environ. Health Perspect. 110 (suppl 1), pp. 25-42, 2002. 